\title{
CONSIDERAÇÕES SOBRE A REPÚBLICA 300o, DE MENOTTI DEL PICCHIA
}

\author{
Daniela Spinelli
}

Não houvesse essa renhida luta entre o sonho e a verdade dentro do tédio da vida que seria da humanidade? Menotti Del Picchia

Depois da criação de $A$ Tormenta, romance histórico no qual descreveu os acontecimentos da breve batalha que tomou de assalto a cidade de São Paulo em 1924', Menotti Del Picchia, sob o signo do trauma, escreve um texto completamente diverso. Distanciando-se das atribuições políticas e da redação do Correio Paulistano, órgão oficial do Partido Republicano Paulista, o escritor mergulha na criação de uma narrativa fantástica. O objetivo não é mais construir um relato realista sobre os bastidores da política nacional, mas "fazer varrer do espírito" as imagens sangrentas "dessa estúpida guerra fratricida” (DEL PICCHIA, 1980, p.56).

1 No dia cinco de julho de 1924, data do segundo aniversário da Revolta do Forte de Copacabana, estourou em São Paulo uma revolta armada comandada pelo general Isidoro Dias Lopes, na qual, o objetivo era desestabilizar a política do "café com leite" (aliança do Partido Republicano Paulista e do Partido Republicano Mineiro) e derrubar o governo de Artur Bernardes, presidente do Brasil. 
Testemunha ocular da revolução de Isidoro Dias Lopes e aliado político do presidente da província de São Paulo, Carlos Campos, o escritor constata na fúria dos revoltosos, que cercaram por quatro dias o bairro de Campos Elísios, o fim de uma época de hegemonia da política oligárquica do café-com-leite. Se as impressões de Menotti Del Picchia sobre o incidente são aterrorizantes, isso ocorre porque ele não suporta a hostilidade ao projeto político desenhado pelos cafezais. Frustrado com a disseminação do movimento tenentista, que culminará na ascensão de Getúlio Vargas ao poder em oposição à velha oligarquia paulista, Menotti Del Picchia rompe com o real e projeta uma dimensão imaginária. Contudo é preciso não perder de vista o fato de que o autor, embora busque inventar uma ficção para "alívio" e "recreação" (DEL PICCHIA, 1980, p.13), mesmo assim admite no prefácio do romance $A$ República $3000^{2}$, ter sido a experiência histórica a levá-lo a criar uma estranha narrativa. Por este motivo, talvez seja possível afirmar que o sentimento de "fratura social favoreça a germinação de experimentos imaginários” (BERRIEL, 2010, p.12).

Motivado pela vontade de não falar do mundo e de reagir contra aquilo que se apresenta como existência verídica, o autor de Juca Mulato propõe purificar-se de uma sociedade degradada ${ }^{3}$ através de um desenho hipotético. Deve-se, portanto, renunciarà realidade na tentativa de realizar os anseios vitais. A história fabulosa da República 3000, publicada em 1930, surge da vontade do escritor de desconectar-se do presente, projetando para além da realidade um outro lugar. $\mathrm{O}$ que podemos perceber é a formação de dois pólos opostos: um negativo - que representa o mundo real e a impossibilidade de realização dos desejos - e um positivo, onde se perde a relação com a vida ordinária, sem abrir mão da possibilidade de realização do ideal no mundo abstrato. Recolhido numa torre de marfim, longe das mazelas da história, o escritor de Itapira descreve a viagem de uma expedição científica, para um lugar além do horizonte, que ignora

2 Sabe-se através do prefácio da obra, que Menotti Del Picchia escreveu A República 30oo, logo depois de terminar a redação d'A Tormenta, publicando-a pela primeira vez em 1930. Depois de inúmeras edições, a obra é republicada sob o título $A$ Filha do Inca, em 1949. No entanto, trata-se do mesmo romance, isto é, sem nenhuma mudança interna. Apenas o título da obra foi alterado, conforme a nota dos editores, pois se temia que o nome A República 300o, poderia gerar confusões, levando o leitor a interpretar como um livro político.

$3 \mathrm{O}$ termo usado, no presente artigo conforme os moldes de G. Lukács, em Teoria do Romance. 
as fronteiras do possível e atinge o extraordinário. Ou seja, a descoberta da existência de uma cidade super desenvolvida no interior do sertão brasileiro.

A epígrafe que abre o primeiro capítulo da República 300o, anuncia:

\begin{abstract}
A Humanidade desbordara dos velhos continentes. Todas as devassas do sertão eram o instinto da espécie dilatando as fronteiras necessárias à expansão da vida. Era chegada a vez das últimas reservas virgens da América (DEL PICCHIA, 1980, p.17).
\end{abstract}

Ora, "os homens sempre sofreram com os limites da existência" (BOSSI, 2003, p.9). Ainda que não exista nenhum tipo de justificativa para a constituição do ser humano no mundo, e o simples viver pareça completamente absurdo, existimos. A ontologia do homem limita sua vida a um certo tempo e espaço definidos. Esta facticidade, que coincide com a sua condição de mortal, porque somos substancialmente uma matéria temporal, determina que a dimensão real do tempo é o agora. Por este prisma, o instante presente ordena a substância da vida humana na impermanência e abre a percepção da existência do tempo passado, como aquilo que se foi e do tempo futuro como aquilo que ainda não é.

Diferentemente dos outros seres vivos também sujeitos a historicidade, o homem é o único animal que conhece a possibilidade de não ser, ou seja, sabe da finitude de sua experiência individual, pois é dotado de consciência histórica. De modo que, através da memória e do esquecimento, organiza a sua existência em relação ao mundo. A essência da existência humana, então, delimitada pelo tempo e pelo espaço, nos impede de extrapolar as esferas da vida. Em conseqüência nenhum resgate pode nos salvar da absoluta contingência da existência humana, a não ser que sejamos capazes de transformar a vida em obra de arte. Cabe portanto a imaginação transcender a realidade, para "os lugares além do horizonte, onde as três dimensões do tempo fluem uma na outra” (BOSSI, 2003, p.9).

Desta forma, talvez seja possível afirmar que o homem é um ser antropologicamente utópico, porque impulsionado pelo desejo e através da razão consegue dar um significado artístico para a sua existência. No auge do Renascimento, Giovanni Pico della Mirandola, superou as bases do pensamento medieval ao anunciar em seu Discurso sobre a dignidade do homem: a ausência de um arquétipo humano definido, isto é, de uma condição anterior à sua existência, libertando-o para definir a sua própria forma e destino. Então, sendo um conjunto indefinido de possibilidades de ser, cabe ao homem conduzir suas potencialidades, para constituir- 
se livremente. "Poderás degenerar até os seres que são bestas, poderás regenerar-te até as realidades superiores que são divinas, por decisão do teu ânimo" (PICO DELLA MIRANDOLA, 1982, p.53). Logo, o ser humano convive com a dualidade entre mediocridade e potência, cabendo a si próprio modelar a sua existência dentro de infinitas possibilidades (SPINELLI, 2010, p.32), pois sua natureza é "vária, multiforme e mutável” (PICO DELLA MIRANDOLA, 1982, p.55). A versatilidade que orienta a natureza humana afasta-o do universo real, projetando novas possibilidades e novos mundos.

Este caráter fundamental da espécie humana se revela também como instinto de sobrevivência e capacidade de responder de forma "flexível aos estímulos da natureza” (QUARTA, 2009, p.232). Em outros termos, dotado de memória e capacidade cognitiva, o ser humano consegue criar e especular soluções possíveis para sua avidez. Impulsionado pelo exercício mental de construção de um paradigma imaginário é capaz de mudar de forma concreta, continuamente o próprio ambiente, revelando-se perspicaz para escapar de situações que ofereçam perigo a sua existência e avançar sobre o desconhecido.

Tomado pelo desejo de conhecer o mundo, o aventureiro, abandona o notório e o seguro, na busca pela superação dos limites impostos pela vida. José Alcântara Machado, na obra Vida e Morte do Bandeirante, publicada em 1929, reproduz uma reflexão bastante curiosa sobre as afinidades entre o marinheiro e o sertanista. Vejamos:

\footnotetext{
Entre o marinheiro e o sertanista são transparentes as afinidades. Resultam das muitas que aparentam com o sertão o oceano.(...) Diante do oceano, como diante do sertão, é o mesmo assombro, é a mesma impressão de infinito e de eternidade, é a mesma vertigem. Só eles imensos e desertos podem saciar a fome de liberdade sem limites que devora o homem, o nomadismo ingênito que o atormenta, o orgulho de bater-se, fraco e pequenino, contra os elementos desatrelados, e de vencê-los. (MACHADO, 1980, p.232)
}

O marinheiro e o sertanista são animados, portanto, pelo mesmo espírito. A vontade de "dilatar as fronteiras" geográficas leva-o "a desbordar dos velhos continentes" na busca pelo inesperado. Durante a contemplação do infinito, no sertão ou no mar, o homem ilude-se com a miragem da eternidade e com a possibilidade de suspender com a lógica temporal que o governa. As "volúpias sobre-humanas" que se apoderam do corpo destes aventureiros, os levam a afeiçoar a alma e o corpo. "Este ganha a elasticidade e a robustez dos monstros marinhos e das feras. $\mathrm{O}$ 
andar, até ele, se modifica"(MACHADO, 1980, p.232) Seguindo esta lógica, o homem, distanciando-se das regras sociais, ganha maior flexibilidade para transformar-se, delineando-se no improvável.

A epígrafe de efeito, exposta propositalmente à margem do primeiro capítulo da República 300o, faz assim uma alusão ao clima das explorações geográficas, que conduziu a humanidade ao descobrimento do Novo Mundo, e modificou o imaginário da população do velho continente. Decerto os relatos de viagem escritos pelos aventureiros estimularam a curiosidade da população européia por suas descrições detalhadas sobre as terras e os povos visitados. A exuberante selva e a nudez dos povos indígenas da costa ameríndia despertaram o sentimento de um sensualismo ingênuo, que remete à imagem de um paraíso terreno. $\mathrm{O}$ sonho escatológico da descoberta de regiões paradisíacas, reservas de ouro e diamante, preenchem o imaginário do velho continente. Dominados pela ideia da existência de uma sociedade "de ouro", não contaminada pelo pecado, os relatos dos descobridores revelam a nostalgia de uma totalidade perdida depois da queda, e a tentativa de retorno ao Éden.

Ora, as cartas sobre o descobrimento do continente americano, que tiveram imensa repercussão pública, evocaram interesse não apenas pelas exposições dos "estranhos" costumes de seres "carentes" de pudor e religião, que vivem sob as regras da natureza, por relatar ritos antropofágicos e a existência de cidades perdidas em lugares remotos, mas principalmente, porque provocaram na população européia o nascimento de uma nova consciência sobre as formas de socialização.

Inegavelmente, Menotti Del Picchia abre a narrativa da República 300o, projetando a imagem da viagem de descobrimento, como abertura para experiência do maravilhoso. Organizada pelo exército brasileiro e sob o comando do Capitão Paulo Fragoso, a campanha militar que partiu da cidade do Rio de Janeiro, no dia 12 de Julho de 19..., tinha como objetivo levantar o mapa orográfico e hidrográfico da Serra do Caiapó e da Bacia do Piquiri. Consagrado nos círculos científicos europeus por seu estudo sobre os sambaquis do sul e no polêmico debate com Dr. Paul Rivet, sobre a primeira onda de migração ocidental para a Terra do Fogo, o Capitão Paulo Fragoso é um homem tomado pela vontade "de conhecer a essência das coisas e os mistérios do mundo" (DEL PICCHIA, 1980, p.27). Esta característica fundamental do erudito personagem levara-o a somar no currículo inúmeras aventuras: "devassas do sertão até as fronteiras guianas; levantamento do mapa da serra do Diabo; descidas ousadas e 
heróicas pelas estradas fluviais da bacia do Amazonas" (DEL PICCHIA, 1980, p.27).

Ainda um jovem de trinta e dois anos, sem nenhuma prévia experiência amorosa, o comandante da Comissão técnica goza da fama de sábio e perito nos perigos da traiçoeira selva brasileira. O autor do célebre estudo sobre a etnografia brasileira pré-colombiana, na missão de reconhecimento geográfico do sertão do Brasil Central encomendada pelo governo federal, contava ainda com o auxílio do destemido Tenente Pina e sua escolta armada. Descendente da longa linhagem de sertanistas brasileiros e parente próximo do Marechal Rondon, o Tenente Pina conduzia a vanguarda do pequeno pelotão de homens a abrir com picadas de foice e machado, caminhos improvisados pela selva inóspita.

Logo no início da viagem acontecem inúmeras desgraças à expedição. Obrigados a deixar os caminhões na cidade de Mineiros e partir pelas vertentes Aporé e Caiapó, aos poucos a tropa de quinze soldados é reduzida para apenas nove, pois quatro homens sucumbiram à malária, o cozinheiro foi vítima de uma jararaca e o último foi engolido pelas violêntas águas do rio Aporé, com duas bestas que carregavam as armas, mantimentos e os instrumentos científicos. Desta forma a jornada de reconhecimento do território nacional torna-se uma catástrofe. Coagidos a viver quase na indigência, a caravana enfrentava a luta permanentemente contra a "tocaia verde. O sertão goiano, bravio e bruto, parecia ir defendendo-se com todas as armas, contra aquela entrada" (DEL PICCHIA, 198o, p.21).

Na exuberante selva, onde "cada tronco tomava a feição hostil e guerreira" (DEL PICCHIA, 1980, p.56) e cada "cipó é uma serpente", os soldados, habituados à dura vida bandeirante, penetram a mata na esperança de encontrar riquezas. A metamorfose acontece porque a floresta é na verdade um universo inexplicável, o "inferno verde", onde "a imaginação cria as mil formas das almas penadas" (DEL PICCHIA, 1980, p.51). A natureza selvagem impõe obstáculos contra o avanço dos exploradores que caminham orientados pelas estrelas na direção da Serra dos Baús. Alimentando-se de caças e raízes, os soldados, vestidos dos farrapos da farda, passam por um processo de animalização. O cabo Maneco "nem tinha mais figura de gente: tufos de pelos pretos rompiam em touceiras hirsutas do queixo e umas falhas de bigode transformavamno num ser exótico, mistura paradoxal de orangotango e espanador" (DEL PICCHIA, 1980, p.56). Tudo se modifica no sertão. Na "natureza o homem é obrigado a contar com suas próprias forças” (MACHADO, 1980, 
p.234) Frente ao perigo e a brutalidade da vida, o homem transforma-se ganhando a "robustez das feras".

Através da deformação da realidade pelo macabro e grotesco, a narrativa assume a forma do horror. A ambiguidade de cada elemento da floresta desperta a insegurança e empolga a imaginação. Trata-se de um mundo dotado de outra lógica da ordem natural que, vista por quem a ignora, parece absurdo e sobrenatural. $\mathrm{O}$ medo do desconhecido cria a imagem de criaturas fabulosas como o curupira, saci, boitatá, caapora e outros monstros que habitam o sertão.

Já na fronteira com o estado do Mato Grosso, o acampamento é atacado por uma tribo de "bugres bravos". O Tenente Pina tenta resistir à ofensiva ordenando aos soldados que disparem contra os invasores. "Com os olhos injetados de sangue" profere em alto tom: "Quero caçar essa macacada!”. (DEL PICCHIA, 1980, p.44) Nas palavras do sertanista é possível notar a violência de predador de índios, que não reconhece no outro um semelhante. Atingido por uma flecha no ventre, o Tenente Pina cai de joelhos, encharcado de sangue. Aproveitando-se da fraqueza do adversário, um forte índio esmigalha-lhe o crânio com um tacape. É curioso notar como a violência contamina todas as esferas da narrativa, seja na disputa entre o colonizador e o selvagem ou entre a natureza e o homem. As forças de destruição do outro parecem encarnar o instinto de sobrevivência da espécie que busca dominar para resistir.

Após a batalha, a expedição científica ficou reduzida ao Capitão Paulo Fragoso, o covarde cabo Maneco, que fugiu durante o conflito, e o fiel cão Faísca. Os sobreviventes procuram enterrar os seus mortos para evitar que os bichos violassem os corpos, e "piedosamente fizeram uma cruz com dois troncos assinalando o túmulo dos heróis”. (DEL PICCHIA, 1980, p.53) Na esperança de sobrevivência de alguns dos companheiros, que haviam sido capturados por selvagens, os três aventureiros partem em busca da tribo de canibais.

Depois de dois dias caminhando bravamente no seio da floresta, os três sobreviventes localizam em um vale a aldeia dos índios guerreiros. Escondidos nas moitas, podem observar a realização de um ritual bizarro. Enquanto seus companheiros-reféns ficam amarrados em postes, índias velhas de seios murchos fervem água em grandes caldeirões sob fogueiras, e os índios dançam em torno dos desgraçados.

Trata-se de um ritual antropofágico. Tema caro para os modernistas paulistas, o canibalismo praticado por algumas sociedades indígenas da América do Sul, tem como objetivo a apropriação violenta das capacidades 
subjetivas do inimigo. Nota-se que a meta não é comer o outro para saciar a fome, mas realizar um ritual com significado religioso, uma vez que os cativos da guerra tornam-se fonte de qualidades através da absorção alimentar. $\mathrm{O}$ ritual é realizado sob a forma de uma grande festa na tribo, onde são encenadas cenas da vitoriosa batalha contra os prisioneiros e danças tradicionais. Os cativos são amarrados com uma corda em troncos e um índio, atráves de um golpe na nuca, rompe o crânio, executando a vítima. $\mathrm{O}$ corpo do prisioneiro deve ser inteiramente aproveitado para a alimentação da tribo. Todos, menos o matador, devem se alimentar da carne do inimigo, para assim incorporar as qualidades do inimigo. Na narrativa, A República 30oo, de Menotti Del Picchia, talvez o ritual antropofágico praticado pelos índios do sertão goiano simbolize uma força de resistência ao processo de colonização; afinal, o primitivo ambiciona devorar o mundo civilizado. Como um desafio à razão ocidental, o ritual canibalista representa um fracasso da missão colonizadora do exército brasileiro nas últimas reservas virgens da América. A aproximação com a cultura antropofágica revela a valorização do universo indianista sul americano como fundamento para uma experiência inovadora. A atração do autor pelo ritual primitivo revela uma tentativa de distanciar-se do racionalismo moderno e pretende construir a identidade nacional na recuperação de elementos de uma cultura "bárbara".

Receosos com o destino dos cativos, o Capitão Fragoso, de tocaia nas moitas, dispara um tiro que atinge o cacique. Descobertos pelos aborígines, fogem pela mata sem olhar para trás, e os dois militares atravessam correndo uma larga planície nos arredores da Serra dos Baús. Longe do perigo, avistam um bizzarro arco no céu, e dominados pela curiosidade, os três andarilhos seguiram na direção da figura geométrica no horizonte. Depois de quarenta kilometros atingiram o bizarro acidente: era um estranho cemitério de ossos, oriundos dos mais diversos tipos de animais e seres humanos de todos os tempos. "Haviam esqueletos de todos os tamanhos; uns miúdos, outros gigantescos. Possuíam alguns as conformações exóticas. Deviam ser uns do primitivo habitante da caverna, o homem da pré-história, o taciturno e feroz companheiro do bisonte. Outros eram de antropóides" (DEL PICCHIA, 1980, p.72). Enquanto o cabo Maneco se admirava com aquele cenário sobrenatural, o Capitão Fragoso estudava as formações ósseas, procurando identificar a origem de cada ossada. Empolgado com a carcaça de um brontossauro, ignora os faniquitos do medroso cabo. 
Entre os ossos era possível identificar objetos feitos de pedra lascada, lindas vasilhas de ouro e cobre, cerâmicas, punhais, vasos, cinturões, lanças e escudos de prata: "uma fortuna incalculável". O cabo Maneco, desinteressado da origem dos tesouros antropológicos, agarrava os objetos "alucinado de alegria". Já Capitão Fragoso, instigado pela origem das peças, era capaz de reconhecer em cada objeto a civilização de um período histórico. "Como achar a razão dêsse museu arqueológico bizarro, perdido no sertão onde encontrava os esqueletos das primeiras manifestações superiores da vida orgânica e os espécimes mais diversos das mais longínquas civilizações?" (DEL PICCHIA, 1980, p.76).

A questão pairava em uma rede de complexas hipóteses sem solução. Dentro do círculo mágico era possível perceber no horizonte o aeroplano que o Ministério da Guerra enviara para resgatar os soldados ao fim da missão. Animados com a perspectiva de salvação, os três sobreviventes pularam para chamar a atenção do piloto. Contudo, quando o aeroplano atravessou a barreira de esqueletos, foi eletrizado por uma forte corrente. O macabro acidente geográfico paralisou o motor e jogou o aeroplano no chão. Assustado, o cão Faísca correu para a linha sinistra do ossário e foi também eletrocutado. Apavorados com o trágico acidente aéreo e a morte do cachorro, os aventureiros sentiam-se sujeitos a uma estranha força que governava os seus músculos, forçando-os a caminhar na direção de uma mata paralela à barreira de ossos. Quando deram por si, estavam dentro de uma estranha cidade de lata no meio do sertão brasileiro. "Cubos metálicos, fenestrados simétricamente, obedecendo a uma rigorosa simplificação geométrica, desenhando as retas largas e imensas das ruas pavimentadas de metal" (DEL PICCHIA, 1980, p. 95). Em pouco tempo os dois militares encontraram o primeiro habitante da cidade: era uma estranha criatura. Tinha a estatutura humana, com duas pernas, dois braços, uma cabeça enorme, um tórax triangular e um olho na testa. "O nariz era apenas um orifício e a boca um pequeno rasgo" (DEL PICCHIA, 1980, p. 88). No peito trazia uma caixa com um pequeno botão metálico, e quando o monstro o apertou, as membranas dobradas transformaram-se em asas que, como uma hélice, vibravam atingindo uma rotação capaz de elevar a criatura aos céus.

O sábio Capitão Fragoso e o ignorante cabo continuaram a caminhar pelo estranho lugar até perceberem-se cercados por milhares de monstros, quando três desses seres avançaram na direção dos dois e perguntaram, em português, como haviam conseguido atravessar a fronteira elétrica da República 300o. O cabo Maneco e o Capitão Fragoso explicaram, então, 
quem eram e como tinham atravessado a barreira de ossos; entretanto, não foram esclarecidos sobre com quem falavam ou sobre o estranho lugar onde se encontravam. Os seres bizarros apenas afirmaram que a mentalidade dos brasileiros era dois mil anos atrasada com relação à civilização da República 300o, sendo portanto impossível dar qualquer explicação naquele momento.

Fragoso e Maneco foram então conduzidos a um magnífico palácio, que servia também para os habitantes da República 3000 como museu histórico. No caminho o Capitão Fragoso admirou-se com a precisão dos movimentos geométricos das criaturas, as ruas quase vazias, sem carros, aeroplanos ou lâmpadas. Aquilo não fazia sentido para o erudito, que imaginava dever ser uma cidade moderna repleta de máquinas e ruídos. A República 3000 era governada por uma civilização avançada que abolira a roda, a indústria e o combustível.

O museu histórico era um palácio de rigorosa arquitetura barroca, parecendo desenhado por Levau, e cercado por um vasto parque no estilo de Lenôtre, cheio de plantas decorativas, estátuas mitológicas e piscinas de mármore. $\mathrm{O}$ museu era o único edifício da República 3000 que servia de habitação para os dois estrangeiros, pois se adaptava aos seus organismos primitivos. Maneco e Fragoso foram conduzidos para dois luxuosos apartamentos. Na sala de ducha puderam tomar banho, fazer a barba e massagens, usufruindo de raríssima coleção de lavandas, sabonetes e toalhas. Após vestirem uma túnica de linho, foram guiados através do jardim até o salão de jantar, onde encontraram uma mesa farta e elegante. Após o jantar os militares retornaram a seus aposentos para uma justa noite de sono.

No dia seguinte o cabo Maneco eo Capitão Fragoso foram apresentados a Faistos e Gurnia, que revelam que, por um erro operacional, ocorrera uma falha na fronteira elétrica, permitindo a entreda dos militares na República 300o. O cabo Maneco foi então informado que deveria substituir o Monstro Capac, a ser sacrificado pela sua imprudência no controle da fronteira.

Os dois prisioneiros foram então levados a uma praça da cidade, onde havia uma enorme estátua de ouro na forma de um minotauro. Tratavase, segundo a explicação de Gurnia, de "um fetiche da raça, uma simples memória arcaica, tal qual o coliseu dos romanos" (DEL PICCHIA, 1980, p. 113). Abriu-se uma porta no monumento e os militares, escoltados por Faistos e Gurnia, desceram uma escada que dava acesso ao interior do monumento. Lá, encontraram um belo homem, que foi apresentado como 
o monstro Capac, o último puro descendente dos quíchuas. Conservado no seu estado semi-bárbaro através de gerações, Manco Capac era o legítimo herdeiro do Império Inca, e devia ser sacrificado pela falha na fronteira elétrica, obedecendo as tradições do seu povo e sendo substituído por Maneco. A função do "monstro" era bastante simples: cabia-lhe fiscalizar manualmente os contatos. O cabo precisaria substituir Capac inclusive porque aos habitantes da República 3000 eram proibidos de exercer trabalhos manuais.

Receoso que o Capitão Fragoso não entenderia a história da República 3000 dada sua constituição atrasada, Gurnia inicia a explicação sobre a história do seu povo, através de sua forma lendária:

\begin{abstract}
...treze meses após a partida de Keftiú, - narra o cronista Ama, de raça sidoniana a serviço do rei Idomine - a nau Cnossos, seguindo o roteiro de um navegador fenício, nativo de Biblos e chamado Arad, naufragou na orla da baía de Marajó! O roteiro de Arad, com caracteres que são uma evolução linear da escrita hieroglífica egípcia, conservamo-lo, com outras relíquias do Cnossos, numa das salas dêste Museu da República. O nome do chefe da expedição cretense Kynir, filho de Hamou, de origem egípcia, que comandou, em terra também, os náufragos até se estabelecerem aqui e fundarem a República, ficou na nossa tradição com o patriarca da pátria 3.ooo. (...) Nossos historiógrafos Melos e Orantes, em monumentais estudos, auxiliados pelo arqueólogo Troades, reconstituíram as lutas da penetração e da posse. Até a gente de Kynir fixar-se nesta região, os acasos da guerra fizeram dar um largo giro, pelo nordeste do continente, contornando a bacia amazônica, pelas terras quíchuas, alcançando e batendo os Uros na margem do Titicaca. A grande invasão do este, fê-los penetrar na bacia do Amazonas, de onde, renteando, pelos vales, o grande maciço central, se localizaram definitivamente no Caiapó. (DEL PICCHIA, 1980, p. 121)
\end{abstract}

Menotti Del Picchia recupera o mito de Atlântida e o transforma na origem da República 30oo. Parece ser comprovado que uma série de desastres naturais, como a erupção do vulcão de Santorini e um enorme tsunami subsequente afetaram gravemente a civilização minoica, que habitava a ilha de Creta, e que, frente a uma rigorosa crise econômica e alimentar criou-se no imaginário popular o mito da existência de uma ilha ou continente onde reinava a justiça, a paz e reservas naturais em abundância.

Marcada pelo estigma da decadência na Idade do Bronze, a civilização minoica, nativa da ilha de Creta, identificada no relato de Gurnia por Cnossos, deslocou-se para Keftiú. Aproveitando-se da frota de navios e da sua potência militar, a civilização minoica, impulsionada pelo instinto 
de sobrevivência, lança-se no mar. Conduzidos por Arad, um navegador fenício, originário da cidade de Biblos, partiram em busca de um novo território para colonizar. Quando a embarcação naufragou na baía de Marajó, o egípcio Kynir conduziu uma expedição pela América do Sul para escolher um lugar onde estabelecer o novo país. O espaço escolhido, depois de um "largo giro" pelo continente Americano, foi o Caiapó.

Através do relato de Gurnia, o Capitão Fragoso compreende a origem daquela sociedade e o porque da existência de um ídolo clássico minóico na praça central. Aproveitando-se também do profundo conhecimento de Gurnia, o Capitão desenvolve um diálogo sobre as diversas teorias e hipóteses de migração humana para o continente americano. O diálogo, bastante erudito, sobre as diversas teorias científicas e culturas, permite ao Capitão Fragoso aprender tal como um ser de uma raça superior a história das civilizações pré-colombianas. Entusiasmado com as descobertas, elaborava uma confusa teia de interpretações quando foi interrompido por Gurnia, que o aconselha a "não se perder em inúteis complexidades".

Gurnia então continua a descrição da história de seu povo:

Nossa história é simples. É a história da quietação e do trabalho. Kynir fixou a prátria neste recanto. $\mathrm{O}$ chão era fértil e nossos ancestrais, valentes. O grau de civilização cretense, mais alto que o inca, fê-la defender-se com vantagem contra os ataques exteriores. Antes da fronteira elétrica, a paliçada, o muro de cinta, foram barreiras que nos defenderam e nos insularam. O pastoreio cedeu à agricultura. Quando Petsafá - o benemérito do primeiro estágio da civilização da República, quase na nossa pré-história, - descobriu a bomba a vapor e começou-se a explorar a hulha e o ferro, o nosso progresso acelerou-se em porporções astrônomicas. (...) Somos um povo pacífico. A compreensão de que devemos bastar a nós mesmos determinou, desde os estágios primitivos da nossa civilização, a limitação do número de cidadões da República. Realizamos o malthusianismo ético e técnico, inicialmente por dispositivos legais, que acabaram formando uma irredutível consciência coletiva, mais imperativa que todos os dispositivos da lei, porque tornou instinto da raça. (DEL PICCHIA, 1980, p.126)

Menotti Del Picchia, para demonstrar o alto grau de desenvolvimento da República 300o, insere o descobrimento da máquina a vapor na pré história dessa civilização cretense. Todo o desenvolvimento do mundo ocidental, o progresso e a revolução industrial, por esta perspectiva tornam-se um estágio obsoleto, ultrapassado, porque a República 3000 já descobrira a cosmodinâmica, a eletricidade cósmica e criou a energia pura. 
Outro dado importante é a prática de limitação da quantidade de habitantes da República através do uso de dispositivos legais, que não são especificados, e da teoria de Thomas Robert Malthus. Malgrado o fato de que esta teoria surgiu no velho continente sob o título "An Essay on the Principle of Population", em 1798, a República 3000 reconhece o seu valor e sua utilidade já nos estágios primitivos de sua civilização, transformando-a em princípio ético da consciência coletiva dos cidadãos. Gurnia ainda alerta que os habitantes da República 3000 são um povo pacífico, que decidiu "processar a sua evolução num âmbito restrito", mas não queriam ser perturbados, tendo por este motivo se isolado do resto do mundo por meio de uma barreira. A região do Caiapó, conforme seu relato, é uma região riquíssima de todos os elementos necessários para a sua civilização, com abundância de minas de carvão, ferro, petróleo e metais preciosos. Gurnia ainda levanta uma questão que se revelará fundamental e contraditória: "Para que imperialismos onde há fartura e bem-estar?" (DEL PICCHIA, 1980, p.127).

Os habitantes da República 3000 conseguiram, através da remodelação do corpo, simplificar ao máximo todo o seu organismo. Eliminaram facultivamente todos os orgãos inúteis do corpo. Não se trata de darwinismo e sim de um processo de elaboração fisiológica consciente. Através do mesmo princípio, os cidadãos criaram novos orgãos, como a hélice para o vôo e novos sentidos, como a televisão, teleaudição e telenergia. Eliminaram ainda qualquer tipo de sentimentalidade, "a vida se reduz a um jogo matemático de certezas. (...)Tudo se reduz a equação cujos termos são possibilidade, realização, dando como resultado uma realidade objetiva" (DEL PICCHIA, 1980, p.199).

Na República 3000 todos crêem na mesma religião, ou seja, na Incógnita Inicial. Todos os homens possuem crenças e religiões enquanto ainda existirem segredos no cosmos para serem desvendados - esclarece Gurnia. Na República, ainda falta resolver uma pura equação matemática. Os ritos são a pesquisa científica, a meditação é o estudo e os altares os laboratórios. A solução desta equação deve ser resolvida com os termos fornecidos pela natureza, e uma vez que a equação solucionada, a última etapa do desenvolvimento da República terá sido vencida.

Pouco se diz sobre as formas políticas da República 3000. Sabese, no entanto, que no estágio da máquina a vapor fora uma autocracia disciplinadora, isto é, um país sob o governo absoluto de um único detentor, mas que agora é governada sob o individualismo anárquico. Não existem leis, nem códigos. Gurnia alerta: “Nosso individualismo anárquico, aboliu 
a regra coativa e formou o imperativo comum da consciência” (DEL PICCHIA, 1980, p.145). Age-se na República 3000 por instinto, através da solidariedade social. Lá existe a paz porque não existe o crime.

\begin{abstract}
Abolimos o criminoso. O organizmo perfeito funciona bem e o bom funcionamento fisiológico e mental é o moral, o justo, o útil, isto é, a possibilidade da coexistência social. O crime é filho da piedade. Eliminamos, desde o berço, o organismo imperfeito, porque tolerá-lo por qualquer sentimentalismo antiprático e anti-social, seria justificar e defender o aparecimento do próprio crime. (DEL PICCHIA, 1980, p.146)
\end{abstract}

Não existem leis ou códigos pré estabelecidos para organização social, porque o organismo é perfeito. Abole-se no nascimento qualquer organismo imperfeito, mas não existe descrição de como se dá esse procedimento. Sabe-se, no entanto, que os cidadãos da República não podem assassinar qualquer criatura.

Mas em um país, onde não existe crime ou cadeia, Capac, Raymi e os dois militares são prisioneiros. O Capitão Fragoso e o cabo Maneco penetraram a República 3000 por acidente, mas a existência de Capac e Raymi, que representam um troféu vivo da história heróica do povo cretense, serve apenas como recordação da vitória dos 3000 sob todas as populações primitivas. Nos dias de festa nacional o palácio museu é aberto à visitação para a população da República, com o objetivo de verificar qual era a forma primitiva do homem na época bárbara. Depois que Pizarro destroçou o Império Inca, os dois prisioneiros tornaram-se os últimos descendentes da Idade de Ouro incaica. Mas a República está determinada a praticar o princípio da utilidade eliminando Capac e Raymi, uma vez que agora, com os militares, o país tem novos elementos destinados aos trabalhos inferiores. Capac será substitudo porque demonstrou negligência na operação do arcaico sistema elétrico da fronteira. Desta forma, obedecendo à pragmática do governo, os prisioneiros incas são condenados à pena de morte, e portanto, realiza-se um crime.

No entanto Gurnia, pondera que somos incapazes de compreender a lógica por trás desta decisão, porque somos indivíduos atrasados e desconhecemos os avanços da civilização. O sacrifício de Capac não é um ritual com significado totêmico ou religioso para a República 30oo, tratando-se da eliminação de um ente inútil para a sociedade. Embora qualquer estrangeiro signifique pouco mais que um touro ou um carneiro para a população do país, "o sacrifício é ainda uma homenagem piedosa 
às formulas místicas que presidem às mentalidades embrionárias" (DEL PICCHIA, 1980, p.143).

O Capitão Fragoso, estupefado com todas as revelações de Gurnia, constata o progresso da sociedade cretense. Sentia-se humilhado diante do desenvolvimento da República 300o, e desejoso de compreender todos os níveis de sua organização social. Atraído por uma linda voz, que vinha do jardim, o Capitão se levanta do leito, em uma noite de insônia ,e deixa a nostalgia do canto preencher a sua alma. O canto evocava na sua memória histórias de contos fantásticos lidos na infância. Aproximando-se do muro que dividia o palácio-museu, reconheceu o vulto de uma mulher: era Raymi, irmã de Capac, uma linda descendente da real estirpe de Manco Capac. Dotada de uma inteligência fora do comum e uma cultura ocidental completa, Raymi é capaz de comunicar-se com o Capitão, pois aprendera o português através do rádio, da televisão e da auto-audição. Raymi relata então militar a história do seu povo. O Capitão Fragoso apaixona-se rapidamente "pela herdeira saqueada da América livre", (DEL PICCHIA, 1980, p.187) e desconstrói o juizo positivo que fizera da República 300o. Enamorado por Raymi e receoso com o destino de Capac e Maneco, passa a planejar uma fuga daquele estranho país.

Incapaz de resistir à opressão do povo da República e de fugir daquele lugar, o Capitão Fragoso é obrigado a comparecer ao sacrifício de Raymi e do irmão. Depois de recusar-se a assassinar os companheiros, o cabo Maneco é drogado com uma bebida e inicia o ritual. Entretanto, antes de sacrificar Capac, uma comoção toma conta dos habitantes da República 3000: a última questão, a Incógnita Inicial, fora enfim solucionada. Finalmente as estranhas criaturas podem migrar, desta vez para outro planeta. Aproveitando-se da oportunidade, os quatro prisioneiros fogem do desenvolvido país esforçando-se para atravessar a fronteira elétrica enquanto ela encontrava-se desativada.

Somente Capac não consegue atravessá-la a tempo e é eletrocutado. Os outros três seguem pela floresta até, finalmente, atingirem um acampamento. Salvos da morte e da prisão eterna, decidem manter em sigilo toda a aventura no país da República 3000 para escapar de possíveis chacotas públicas. O Capitão Fragoso casa-se com Raymi, e Maneco retorna para os braços de sua esposa com uma pequena fortuna recolhida do ossário. Por conta da ascensão social, o cabo pode gozar dos momentos

4 Carlos Eduardo Ornelas Berriel, no prefácio do livro Onze Vezes Utopia, escreve: "O utopista capta problemas de seu mundo e sua época, e constrói uma projeção dos 
livres ao lado da família, contando suas histórias na mata, como fábula de um país maravilhoso.

Como vimos, trata-se de uma narrativa na qual o autor, Menotti Del Picchia, desloca-se do aqui-agora, articula uma reflexão "sobre as variáveis hipotéticas da natureza humana” (RACAULT, 2009, p.30) e projeta ${ }^{4}$ "para fora do presente uma aspiração a um "mundo melhor" situado no porvir" (RACAULT, 2009, p.37). O relato de viagem para o fantástico, permite ao leitor confrontar dois mundos distintos e ponderar sobre os aspectos positivos e negativos de cada sociedade. Trata-se, portanto, de um exercício crítico que formaliza as contradições do presente, fornece dados para uma avaliação racional sobre o ser e a sociedade.

Essa é uma das raras histórias de ficção científica produzidas pelo Modernismo brasileiro, e que revela, talvez, o desejo utópico de formação de uma modernidade não industrial.

\section{REFERÊNCIAS BIBLIOGRÁFICAS}

BERRIEL, Carlos Eduardo Ornelas. Tietê, Tejo, Sena. A obra de Paulo Prado. Campinas: Papirus, 2000.

. Onze Vezes Utopia. Estudos Comparados. Campinas: Iel/UNICAMP, 2010.

BOSSI, Giovanni. Immaginario di Viaggio e Immaginario Utopico. Milano: Mimesis, 2003.

BRITO, Mário da Silva. "Uma Literatura Premonitória. Ângulo e Horizonte. São Paulo: Martins, 1969

CARNEIRO, André. Introdução ao estudo da "Science-Fiction". São Paulo: Imprensa Oficial do Estado, 1967.

CARUSO, Roberto de Souza. Ficção Científica, Fantasia e Horror no Brasil. Belo Horizonte: UFMG, 2003.

CASTRO, Ana Claudia Veiga de. A São Paulo de Menotti Del Picchia. São Paulo: Alameda, 2008.

CUNHA, Fausto. A Ficção Científica no Brasil. São Paulo: Summus, 1974.

DEL PICCHIA, Menotti. A Filha Inca. São Paulo: Martins, 1980.

mesmos: tendo seus problemas e suas causas alterados de determinada forma, qual seria o seu cotidiano? Como seria este mundo e esta época se a direção essencial fosse anterada conforme uma determinada idéia ordenadora, imaginada pelo utopista. A imagem desta totalidade virtual, nascida da simbiose entre ficção e ética social, é a utopia. (2010, p. 12) 
A Tormenta. São Paulo: Martins, 1958.

. A Longa Viagem. São Paulo: Martins, 1970.

. A Longa Viagem 2플. Etapa. São Paulo, Martins, 1972.

FAUSTO, Boris. História do Brasil. São Paulo: Edusp, 1995.

FIKER, Raul. Ficção Cientifica. Rio Grande do Sul: L\&PM, 1985.

FREEDMAN, Cral. Critical Theory and Science Fiction. Hanover: Wesleyan Press, 2000.

GINWAY. M. Elizabeth. Fiç̧ão Científica Brasileira. São Paulo: Devir, 2005.

JAMESON. Fredric. Archaeologis of the Future. London: Verso, 2005.

MACHADO, Alcântara. Vida e Morte do Bandeirante. Belo Horizonte: Itatiaia, 1980

MIRANDOLA, Giovanni Pico della. Discurso sobre a dignidade do homem. Lisboa: Presença, 1982.

OTERO, Léo Godoy. Introdução a uma História da Ficção Científica. São Paulo: Lua Nova, 1987.

QUARTA, Cosimo. "Livelli del pensiero utopico: antropologia, storia, letteratura”. In: Morus - Utopia e Renascimento. №6. Campinas: Unicamp, 2009.

RACAULT, Jean-Michel. "Da idéia de perfeição como elemento definidor da utopia: as utopias clássicas e a natureza humana”. In: Morus - Utopia e Renascimento. № 6. Campinas: Unicamp, 2009.

REALE, Miguel. Menotti Del Picchia. Rio de Janeiro: AC\&M, 1988.

ROBERTS, Adam. The History of Science Fiction. New York: Palgrave, 2007.

STOCKWELL, Peter. The Poetics of Science Fiction. Harlow: Pearson, 2000. 
